\title{
BCG: who were Calmette and Guérin?
}

\author{
ALEX SAKULA \\ Emeritus Consultant Physician, Redhill General Hospital, Surrey
}

\begin{abstract}
"En toutes choses, je crois, le secret du succès est dans les longs efforts. Par la persévérance dans la recherche, on finit par acquérir ce que j'appelle volontiers l'instinct de verité."-LOUIS PASTEUR
\end{abstract}

The abbreviation BCG has entered most languages, since many millions of human beings throughout the world by this vaccine have been protected against tuberculosis. There is at the present time considerable debate about the role of BCG in the control of tuberculosis in the future, but there can be little doubt that, during the past four or five decades, the vaccine has been an important weapon in the fight against tuberculosis.

The two Frenchmen whose names are enshrined in the letters BCG deserve continued universal recognition for their great contribution to preventive medicine. The 50th anniversary of the death of one of them-Albert Calmette-presents an appropriate occasion to inquire what manner of men they were, to recall the story of their lives, and to relate the early history of BCG vaccination.

\section{Albert Calmette (1863-1933)}

Leon Charles Albert Calmette was born on 12 July 1863 in Nice, where his father, Guillaume Calmette, descended from a peasant family in Cantal, was a lawyer in the préfecture. His mother, Adèle Reine Charpentier, died when Albert was barely 2 years old; his father remarried and Albert was reared by his stepmother, Marie Quiney. Albert was the youngest of three sons, one of whom, Emile, became an Army physician, while the other, Gaston, was a journalist.

The family moved first to Clermont-Ferrand in 1873 and then to St Brieuc in Brittany in 1876 . Albert attended the lycée in Brest, where a typhoid epidemic led to the death of 10 of his fellow pupils; his own health was impaired, with the result that he could not fulfil his youthful ambition to join the navy as a sailor. In 1877 he continued his education in St

Address for reprint requests: Pilgrims Corner, Pilgrims Way, Reigate, Surrey

Accepted 15 August 1983
Brieuc at St Charles College-a Dominican institution-where he obtained his baccalauréat. Having decided on a medical career, he entered the Naval Medical College at Brest in 1881. After two years of medical studies, he was given the rank of aide-médecin and sent to serve in the Far East, where he saw action in Hong Kong, Amoy, and Formosa from 1883 to 1885 . In Hong Kong he met the great English pioneer of tropical medicine, Patrick Manson (1844-1922), who demonstrated to him his discoveries in filariasis. In 1885 Calmette returned to France to complete his medical studies and in 1886 he qualified MD Paris with a thesis on filariasis.

Calmette then served in the French Congo, in Gabon, where he studied sleeping sickness and blackwater fever. On his return to France in 1888, he married Emilie de la Salle, who later bore him two sons. He was then posted to Saint Pierre and Miquelon, French islands off Newfoundland, where he spent 18 months and was engaged in research on a red spotted condition of salted cod (rouge de la moru); he established its microbial origin and showed that it could be prevented by adding sodium sulphate to the salt.

Calmette had by now decided to pursue a career of scientific research in tropical diseases. In 1890 he joined the French Colonial Medical Service and immediately obtained leave to attend one of the first courses in microbiology given by Émile Roux (1853-1933) at the Pasteur Institute in Paris (which had opened in 1888). He made such a good impression that when the French Government decided to set up three Pasteur Institutes in Indo-China Louis Pasteur (1822-1895) himself recommended that Calmette should take charge of the one in Saigon. In the next two years (1891-3) Calmette organised the vaccination campaign against smallpox and rabies in Saigon and commenced his researches into snake venom. In 1893 a bad attack of dysentery forced him to return to France, where at the Pasteur Institute in Paris he continued his researches on snake venom and succeeded in producing a polyvalent antisnake venom serum, probably one of the first-if not the first- to achieve this. He was expert in handling snakes, but in 1901 he was bitten on the right 
index finger by a particularly venomous variety. He promptly injected himself with his own serum and recovered, although he lost the tip of the finger. Of this incident he wrote: "Le venin n'était pas en cause, mais le serpent avait évidemment négligé de se rincer la bouche." He also recorded a fight between a cobra and a mongoose well before Rudyard Kipling.

During the severe epidemic of plague in the Far East in 1894 (the year which saw the simultaneous discovery of the plague bacillus by Alexandre Yersin (1863-1943) in Saigon and by Kitasato (18521931 ) in Hong Kong) Calmette worked on antiplague serum, improving the one prepared by Yersin.

In 1895 Calmette was appointed as the first director of the newly founded Pasteur Institute in Lille. It was in Lille that he was to spend the next 24 years and where he was to carry out his momentous work on the control of tuberculosis and its prevention by BCG. He required an assistant experienced in the veterinary field and was glad when Camille Guérin was appointed in 1897.

Apart from his work on tuberculosis Calmette made important contributions to the public health with the introduction of sewage purification by biological means and the organisation of the campaign against ankylostomiasis in the coalmines of northern France. In 1899 he was summoned to Portugal to help control the plague epidemic in Oporto. In 1910 he founded another Pasteur Institute in Algiers and, at the invitation of the Greek government, a similar institute in Athens.

The year 1914 proved to be catastrophic for Calmette. His brother Gaston, now editor of Le Figaro, was assassinated for political reasons. The outbreak of the first world war saw the rapid German occupation of northern France. Calmette was ordered to remain at his post at Lille, where he had to contend with an epidemic of typhoid among the German occupying troops, for whom he prepared vaccines and sera. Throughout the war Calmette was virtually a prisoner in the Pasteur Institute in Lille. In 1918 Madame Calmette was arrested and deported to Germany and was released only after six months. Calmette felt very bitterly towards the enemy and when the famous German bacteriologist August von Wassermann (1866-1925) called on him in Lille during the war Calmette refused to receive him.

Emile Roux had been director of the Pasteur Institute in Paris since 1904. In 1917, after the death of Elie Metchnikoff (1845-1916), Calmette was appointed assistant director of the Pasteur Institute in Paris, but was not able to take up this post until the war ended. When he did so in 1919, he left Guerin behind in Lille to continue his research into

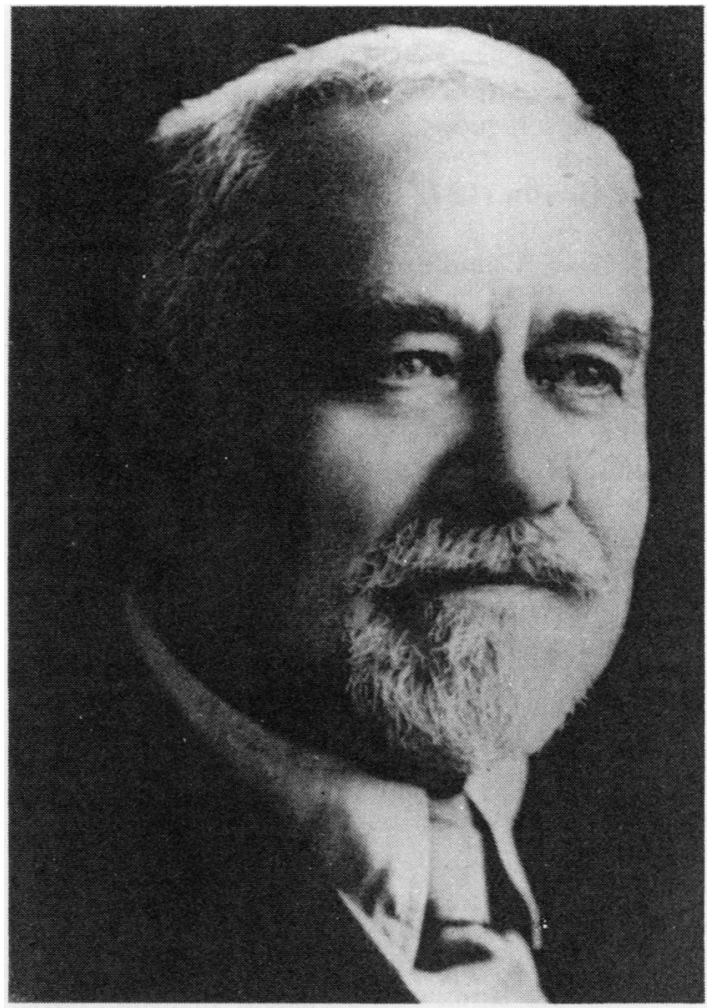

Fig 1 Albert Calmette. (Reproduced by courtesy of the Pasteur Institute, Paris.)

tuberculosis of cattle, and at the Pasteur Institute in Paris he set up a special laboratory for tuberculosis and BCG with Leopold Nègre (1879-1961) and Alfred Boquet (1979-1947) as his assistants. Calmette's residence in Paris was 61 Boulevard des Invalides, $7 \mathrm{e}$; but he moved his office and library into Pasteur's former apartments on the second floor of the institute.

His numerous scientific achievements brought many honours to Calmette (fig 1). He was elected a member of the French Academy of Science in 1907 and of the French Academy of Medicine in 1919. $\mathrm{He}$ had been created Chevalier, Légion d'Honneur, in 1893 and in 1928 he was elevated to the Grand Cross of the Order. He presided over the first congress of the International Union against Tuberculosis held in Paris in 1920.

Calmette had always been of an optimistic, cheerful disposition but the Lübeck disaster in 1930 placed a great strain on him and, although he lived to see BCG vindicated, his spirit was broken and his health broke down. After a short illness, when he was attended by $\mathrm{Dr}$ Pasteur Vallery-Radot 
(Pasteur's son-in-law), he died in Paris on 29 October 1933, aged 70. His remains were interred in the crypt of the Pasteur Institute, Paris, where Pasteur himself reposes. ${ }^{1-2}$

\section{Camille Guérin (1872-1961)}

Jean Marie Camille Guérin was born on 22 December 1872 in Poitiers. His father, Eugene Guérin, was a public works contractor; his mother was Marie Augustine Desmars. Camille was 10 when his father died and his mother remarried. His stepfather, Monsieur Venion, was a veterinary surgeon and it was his influence which directed Camille towards a veterinary career.

In 1892 Guerin entered the Ecole Alfort, the famous veterinary school near Paris, whose director was at that time Edmond Nocard (1850-1903). Nocard, himself a pupil of Pasteur, arranged for the students to attend the celebration in 1892 of Pasteur's 70th birthday, which was held in the presence of Carnot, the French President, and distinguished visitors including Lord Lister. Guérin was enormously impressed by the occasion and it now became his ambition to undertake research on infectious diseases in the veterinary field. As a student, he was entrusted by Nocard to convey precious early samples of antidiphtheria and antitetanus sera from Alfort to Roux at the Pasteur Institute, Paris.

Guerin graduated at Alfort in 1896 and in the following year, on the recommendation of Nocard, he was appointed as assistant to Calmette at the newly opened Pasteur Institute in Lille. The laboratories were in the Halle aux Sucres and it was not until 1899 that the new building of the institute was inaugurated in the presence of Pasteur's widow, Metchnikoff, and others. Guérin's first post was préparateur of vaccines and sera, and he became especially involved in the preparation of antisnake venom serum and the standardisation of smallpox vaccine; but from 1900 he was drawn to the research on tuberculosis conducted by Calmette. He later related how Calmette made him give a solemn promise to devote himself completely to the fight against tuberculosis. By 1907 he had risen to the rank of chef de laboratoire.

Guérin married and had a son and a daughter. During the first world war, while he and Calmette were forced to remain at the Pasteur Institute in Lille, the children were evacuated but his wife remained with him throughout the war; she died just before the Armistice. When Calmette departed for Paris in 1919, Roux was director of the institute at Lille and Guerin was promoted to chef de service, continuing his animal experiments on tuberculosis and BCG. In 1928 Calmette called Guérin to Paris.

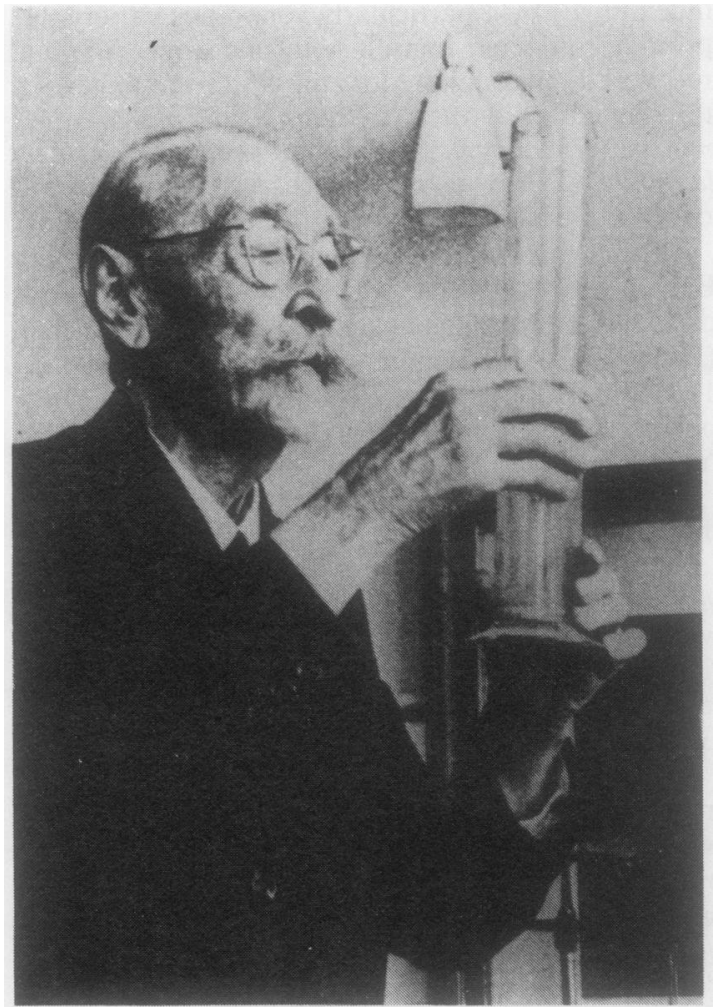

Fig 2 Camille Guerin. (Reproduced by courtesy of the Pasteur Institute, Paris.)

After 31 years at Lille, Guérin was sad to leave and wrote later to Roux: "J'ai laissé la moitié de mon coeur à Lille, et l'autre moitié n'est pas encore guérie de cet abandon."

At the time of the Lübeck disaster in 1930 Guérin (like Calmette) was under great strain, but he rode the storm and was delighted when BCG was exonerated. The new BCG laboratories in Paris were opened in 1931 and Guérin became its chef de service.

In 1933 Guérin lost his two great collaborators-first Calmette and five days later Roux. Guerin remained active at the Pasteur Institute, Paris, until 1943, when he retired at the age of 70 ; he continued as honorary director and resided in an apartment in rooms converted from Calmette's old tuberculosis laboratory.

Guerin was noted for the perfection of his laboratory experimental technique (fig 2). He retained his innate modesty despite the fame which deservedly came to him and the many honours he received both in France and abroad. In 1934 he became a member of the French Academy of 


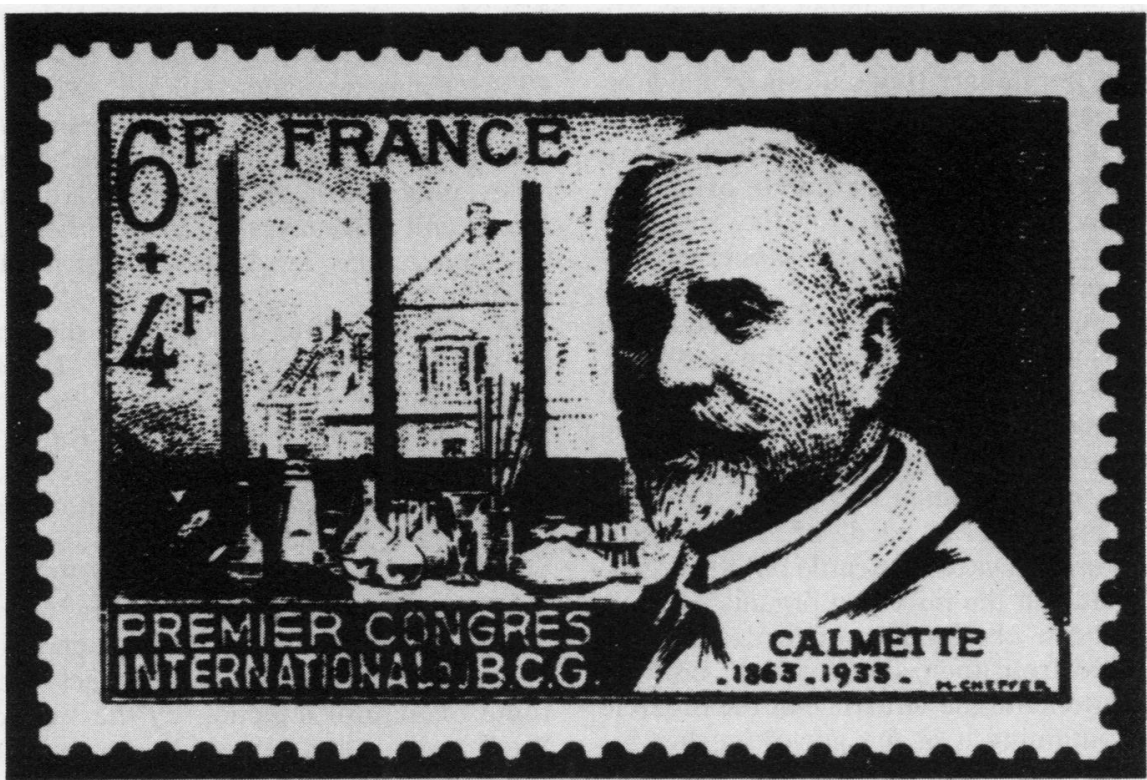

Fig 3 Postage stamp issued on the occasion of First International BCG Congress, 1948, depicting Albert Calmette.

Medicine, of which he was president in 1951-a signal distinction for a non-medical scientist. In 1948 he had the pleasure of presiding over the first International BCG Congress, when 300 delegates from 40 countries met in Paris and Lille, and a special postage stamp was issued, although only Calmette's portrait was featured (fig 3). In 1955 he was created Grand Officier, Légion d'Honneur, and in 1958 the French Academy of Science awarded him a prize of one million francs. In 1960 he was elected an Honorary Member of the International Union against Tuberculosis.

Guérin died in Paris on 9 June 1961, in his 89th year. He was buried at Châtellerault, near Poitiers, where a town street, a hospital, and a lycée now carry his name..$^{3-4}$

\section{The birth of BCG}

When Calmette was appointed director of the Pasteur Institute at Lille in 1896, the main public health problem with which he had to contend was tuberculosis. The death rate for tuberculosis in Lille was 300 per 100000 .

At the social level, he founded in 1901 the first antituberculosis dispensary in Lille, which he named the Préventorium Emile Roux. This was only four years after Sir Robert Phillip in 1897 established the first of its kind, the Victoria Dispensary for Consumption in Edinburgh. In Paris the first such dis- pensary was named after Albert Calmette. Calmette also opened in 1905 the first French public sanatorium at Montigny-en-Ostrevant.

At the scientific level, Calmette addressed himself to the possibility of preventing tuberculosis by means of a specific vaccine. Robert Koch had discovered the tubercle bacillus in 1882 (Calmette was then still a student) and introduced tuberculin in $1890 .{ }^{5}$ Tuberculin proved to be a great disappointment as a cure but it vindicated itself as a diagnostic tool by providing evidence of previous infection by and sensitivity to the tubercle bacillus. In 1903 Clemens von Pirquet (1874-1929) introduced his simple technique of the tuberculin skin scratch test and in 1907 published a paper on his concept of "allergy" to the tubercle bacillus. In the same year Calmette described the conjunctival tuberculin test, ${ }^{\circ}$ which was proposed independently by Alfred Wolff-Eisner (1877-1948) in 1908. The conjunctival test, however, proved to be unsatisfactory and in 1908 Charles Mantoux (1877-1947) devised the more convenient intradermal tuberculin test. In 1908 also, Ernst Moro (1874-1951) introduced the tuberculin jelly test.*

Calmette associated tuberculin sensitivity with immunity and considered that hypersensitivity

*In 1937, this was developed further by Hermann Vollmer (1896-1959) as the tuberculin patch test; and in 1951, Frederick Heaf (1894-1973) invented the multiple puncture technique, of which the Tine test is a recent further refinement. 
resulted from infection by the living organism. He also took note of the observation that it was rare to find progressive pulmonary tuberculosis in individuals who had previously suffered from tuberculous glands of the neck (the so-called Marfan's Law, 1886). ${ }^{7}$ He therefore sought a method of artificially stimulating specific immunity to the tubercle bacillus, along the lines already pioneered by Pasteur in his antirabies vaccine.

There had been previous attempts to produce an antituberculosis vaccine but they were unsuccessful. Tubercle bacilli killed by boiling or by chemical treatment proved ineffective. A live vaccine appeared to be needed; but small doses of virulent tubercle bacilli, either human or bovine, were too dangerous. Human tubercle bacilli of lowered virulence had been used to vaccinate cattle but the organism appeared later in the milk. An organism of low virulence had been obtained from turtles but the vaccine prepared from them did not take; nor was an attempt to attenuate the virulence of the tubercle bacillus by maintaining it in the gut of leeches for many months any more successful.

This was the state of knowledge in 1900 , when Calmette and Guérin, at the Pasteur Institute in Lille, commenced their search for an antituberculosis vaccine. As happens often in the history of science, serendipity played a large part in their success. They cultivated tubercle bacilli on a glycerine and potato medium but found it difficult to produce a homogeneous suspension of the bacilli. In an attempt to counteract their tendency to clump they tried the effect of adding oxbile to the medium and, to their surprise, they noted that subculture led to a lowering of the virulence of the organism. It was this fortuitous observation that led them to undertake their long term project of producing a vaccine from this attenuated tubercle bacillus.

In 1908, starting with a virulent bovine strain of tubercle bacillus supplied by Nocard (originally isolated by him in 1902 from the udder of a tuberculous cow), they cultured it on their bile, glycerine and potato medium and then proceeded to subculture at roughly three weekly intervals. By 1913 they were prepared to initiate a vaccination trial in cattle, but the outbreak of the first world war interrupted this. Subculturing was continued throughout the German occupation of Lille, despite the greatly increased cost of potatoes and the difficulty of obtaining suitable oxbile from the abattoir: this they managed to obtain by grace of the veterinary surgeons of the German occupying force. By 1919, after about 230 subcultures carried out during the previous 11 years, they had a tubercle bacillus which failed to produce progressive tuberculosis when injected into guinea pigs, rabbits, cattle, or horses. At Guérin's sugges- tion, they named it Bacille Bilié Calmette-Guérin; later they omitted "Bilie" and so BCG was born. By 1924 Calmette and Guérin were sufficiently confident to pronounce the organism a virus fixe.

During the four years of the war, Calmette spent his evenings writing his major work on tuberculosis, L'Infection Bacillaire et la Tuberculose, Chez l'Homme et Chez les Animaux, which was published in $1920 .^{8}$

In 1921 Calmette decided that the time was ripe for a trial of the vaccine in man. The first human administration of BCG was by Benjamin WeillHallé (1875-1958) assisted by Raymond Turpin (1895-) at the Charite Hospital, Paris. A woman had died of tuberculosis a few hours after giving birth to a healthy infant. On 18 July 1921 , WeillHalle and Turpin gave a dose of BCG by the oral route to the infant. There were no undesirable sequelae. The oral route was chosen since Calmette considered the gastrointestinal tract to be the usual route of natural infection by the tubercle bacillus. Weill-Halle then tried the subcutaneous and cutaneous routes on other infants but local reactions were objected to by the parents, and so the oral method was continued, an emulsion of BCG prepared by Boquet and Nègre being used. By 1924 they were able to report a series of 664 oral BCG vaccinations of infants. ${ }^{9}$ The Pasteur Institute at Lille now began the mass production of BCG vaccine for use by the medical profession. From 1924 to 1928114000 infants were vaccinated without serious complications. ${ }^{10}$ In 1928 Calmette called Guérin to join him in Paris, since he did not feel it necessary for Guérin to continue the BCG experiments on animals in Lille. By 1931 there was a special laboratory for the preparation of BCG and Guérin was placed in charge.

The method of BCG vaccination was therefore proved to be safe. But just as important was the question of its effectiveness. The statistics of Calmette and Guérin showed a fall in tuberculosis mortality among those susceptible infants who had been vaccinated with BCG. Outside France BCG vaccination was being taken up also, especially in Barcelona by Luis Sayé; and in the Scandinavian countries Arvid Wallgren" in Göthenburg and Johannes Heimbeck ${ }^{12}$ in Oslo pioneered the cutaneous administration of BCG. In Great Britain, however, there continued to be considerable scepticism and the statistics of Calmette and Guérin were strongly criticised in 1928 by Professor M Greenwood. ${ }^{13}$ Moreover, in the United States Petroff and his colleagues at Trudeau Sanatorium reported in 1929 that in a specimen of BCG supplied by Calmette they had isolated virulent tubercle bacilli, casting grave doubt on Calmette's assertion that BCG was a 
virus fixe. ${ }^{14}$ Despite these disturbing reports, Calmette and Guérin remained confident that BCG was safe.

\section{The Lübeck disaster (1930)}

In 1930 the tragic disaster at Lübeck shattered confidence in BCG. In this northern German town, a scheme to vaccinate newborn babies was undertaken by Professor Deycke, director of the Lübeck General Hospital, and Dr Alstaedt, chief medical officer of the Lübeck Health Department. BCG was supplied from the Pasteur Institute, Paris, but prepared for administration in the tuberculosis laboratory in Lübeck and the oral route was used. After four to six weeks a large number of the infants developed tuberculosis. Of 250 vaccinated, there were 73 deaths in the first year and another 135 were infected but recovered. Ten of the parents took legal action and the Attorney-General of Lübeck instigated criminal proceedings against Professor Deycke, Dr Alstaedt, Dr Klotz, and the matron of the hospital. The German government set up an inquiry headed by Professor Bruno Lange of the Robert Koch Institute, Berlin, and Professor Ludwig Lange of the German Ministry of Health. After 20 months their report exonerated BCG as the cause of the disaster, which they attributed to negligent contamination of the vaccine by virulent tubercle bacilli in the Lübeck laboratories. ${ }^{1516}$ Two of the doctors concerned were given sentences of imprisonment.

As the news of the Lübeck disaster spread around the world, Calmette and Guérin were the objects of considerable criticism and both men came under great strain. In August 1930, at the Oslo meeting of the International Union against Tuberculosis, Calmette defended himself and received a great ovation. Though the report of the German inquiry exonerated BCG as the cause of the disaster, confidence in the vaccine had been undermined. In 1931 Calmette wrote an epilogue on the Lübeck disaster. ${ }^{17}$ In France BCG was now less popular, while in Britain the authorities still hesitated to advocate the use of the vaccine. In the Scandinavian countries, however, BCG continued to be administered widely.

\section{Later developments in BCG vaccination}

It was not until the devastation of the second World War, with resultant large epidemics of tuberculosis both in Europe and in Asia, that BCG came to be used on a massive scale. The administration of BCG by multiple puncture as well as the production of freeze dried BCG facilitated large scale vaccination programmes.

In Europe the campaign to vaccinate children in Hungary, Poland, and Germany was initiated by the Danish Red Cross. In 1948 they were joined by the Swedish Red Cross and Norwegian Relief for Europe, under the auspices of the United Nations International Children's Emergency Fund (UNICEF). The BCG campaign was now extended to the rest of the world (International Tuberculosis Campaign or Joint Enterprise) and more than 30 million $\mathrm{BCG}$ vaccinations were administered $^{18}$; while in Japan a national campaign achieved BCG vaccination of 43 millions of the population.

There was therefore a strong body of opinion in favour of BCG vaccination, yet there remained many parts of the world where scepticism continued to reign, especially in the United States, ${ }^{19}$ even though considerable evidence in favour of BCG had been provided in studies among the North American Indians. ${ }^{20}$ In Britain there was also considerable hesitation to use BCG, but in 1950 the Medical Research Council undertook a large controlled trial of the effectiveness of BCG vaccination in 50000 adolescents and young adults. Five reports during the next 20 years (the final one in 1972) showed conclusively that BCG offered an $80 \%$ protection from serious tuberculosis infection, but this degree of protection was less evident towards the end of the trial. ${ }^{21}$

Because of the radical decrease in tuberculosis in the Western world, the use of BCG now tends to be restricted to selected groups, such as medical and other health workers and contacts of infectious tuberculosis patients, especially among the susceptible immigrants. But in the poorer underdeveloped areas of the world, where tuberculosis continues to be a major health problem, BCG vaccination still has an important part to play; and there is evidence that it may help also in the control of another "acid fast" disease, leprosy.

\section{Commemorative plaque in Lille}

In the veterinary laboratory of the Pasteur Institute in Lille a commemorative plaque was erected in 1948 at the time of the first International BCG Congress. The words, composed by Guérin, read:

\author{
DANS CE LABORATOIRE \\ DE 1904 À 1928
}

ALBERT CALMETTE ET CAMILLE GUÉRIN UNIS AUTANT PAR L'ESPRIT QUE PAR LE COEUR ONT PURSUIT LES RECHERCHES QUI ONT ABOUTI À LA PRÉVENTION DE LA TUBERCULOSE PAR LE BCG. 


\section{References}

${ }^{1}$ Kervran R. Albert Calmette et le B.C.G. Paris: Hachette, 1962.

${ }^{2}$ Bernard N. La vie et l'oeuvre de Albert Calmette. Paris: Michel, 1961.

${ }^{3}$ Dalloux Y. La vie et l'oeuvre de Camille Guérin. (Thèse pour le Doctorat Veterinaire d'Alfort, No 99.) Paris: Copedith, 1969.

${ }^{4}$ Bretey J. Neerologie: Camille Guérin. Rev Tub (Paris) $1961 ; 25$ (ii):695-700.

${ }^{5}$ Sakula A. Robert Koch: centenary of the discovery of the tubercle bacillus, 1882. Thorax 1982;37:246-51.

${ }^{6}$ Calmette LCA. Sur un nouveau procédé de diagnostic de la tuberculose chez l'homme par l'ophtalmoréaction à la tuberculine. Compt Rend Acad Sci (Paris) 1907;144:1324-6.

${ }^{7}$ Marfan AB. De l'immunité conférée par la guérison d'une tuberculose locale pour la phtisie pulmonaire. Arch Gen Méd 1886;57:575.

${ }^{8}$ Calmette LCA. L'infection bacillaire et la tuberculose chez l'homme et chez les animaux. Paris: Masson, 1920.

${ }^{9}$ Calmette LCA, Guérin C, Weill-Hallé B. Essai d'immunisation contre l'infection tuberculeuse. Bull Acad Méd. (Paris) 1924;91:787-96.

${ }^{10}$ Calmette LCA, Guérin C, Nègre L, Bouquet A. Sur la vaccination preventive des enfants nouveau-nés contre la tuberculose par le BCG. Ann Inst Pasteur 1927;41:201-32.
"Wallgren A. Value of Calmette vaccination in prevention of tuberculosis in childhood. JAMA 1924;103: 1341 .

12 Heimbeck J. Tuberculosis in hospital nurses. Tubercle 1936;18:97.

${ }^{13}$ Greenwood M. Professor Calmette's statistical study of B.C.G. vaccination. Br Med J 1928;i:793.

14 Petroff SA, Branch A, Steenken W. A study of Bacillus Calmette-Guérin (B.C.G.). Am Rev Tuberc 1929;19:9.

${ }^{15}$ Lange B. Weitere Untersuchungen zur Klärung der Ursachen der Unglucksfälle in Lübeck. Tuberk $1931 ; 62: 335-51$.

${ }^{16}$ Lange L, Prescatore H. Die Säuglings tuberkulose in Lübeck. Berlin: Springer 1935.

${ }^{17}$ Calmette LCA. Epilogue de la catastrophe de Lübeck Presse Méd 1931;39:17.

${ }^{18}$ International Tuberculosis Campaign. Copenhagen: International Tuberculosis Campaign, 1951;178-80.

${ }_{19}$ Anderson AS et al. The case against B.C.G. Br Med J 1959;i:1423-30.

${ }^{20}$ Arenson JD, Palmer CE. Experiences with B.C.G. vaccination in the control of tuberculosis among North American Indians. Publ Health Rep Wash 1946;61:802.

${ }^{21}$ Hart P. D'arcy, Sutherland I. BCG and vole bacillus vaccines in the prevention of tuberculosis in adolescence and early adult life. $\mathrm{Br} \mathrm{Med} J$ 1977;ii:293-5. 